\title{
Representação política em contextos de neoliberalismo e austeridade: possíveis contribuições analíticas a partir da sociologia fiscal
}

\author{
Sérgio Mendonça Benedito ${ }^{1}$ \\ https://orcid.org/0000-0002-0982-4626
}

\section{Resumo}

\begin{abstract}
Referindo-se à teoria política e estudos empíricos sobre o desempenho das democracias contemporâneas, este artigo tem como objetivo avaliar a hipótese da crise de representação sob uma perspectiva informada pela economia política. Em um primeiro momento apresento uma revisão da literatura sobre representação política, fazendo menção àquelas principais pessoas que marcaram o debate como Hanna Pitkin, Bernard Manin e Nadia Urbinati. A seguir destaco alguns estudos empíricos sobre a dinâmica das democracias na atualidade, recorrendo a obras de autores como Peter Mair, Roberto Foa e Yascha Mounk, e mais especificamente trato sobre a democracia em contextos de neoliberalismo e políticas de austeridade, com recurso aos escritos de Colin Crouch, Donatella della Porta e Wendy Brown - entre outros, como Colin Hay, que abordaram o fenômeno da despolitização. $O$ que se extrai deste exercício, a partir de uma perspectiva informada pela sociologia fiscal, é que ao menos as obras clássicas da teoria da representação deixam em segundo plano a crescente assimetria entre representantes e representados e a alta desigualdade entre cidadãos e cidadãs. Assim, sugiro que é necessário trazer esses aspectos ao primeiro plano, tendo em conta o contexto político, econômico e social em que se desdobra o processo da representação.
\end{abstract}

Palavras-chave: Teoria democrática; Crise da democracia; Sociologia fiscal; Economia política; Representação política.

\section{Abstract}

Political representation in contexts of neoliberalism and austerity: possible analytical contributions from fiscal sociology

Based on political theory and empirical studies on the performance of contemporary democracies, this article aims to assess the hypothesis of the crisis of representation from a perspective oriented by political economy. Initially I present a review of the literature on political representation, quoting those

1 Sérgio Mendonça Benedito é doutorando em Ciência Política pela Faculdade de Filosofia, Letras e Ciências Humanas da Universidade de São Paulo (PPGCP/FFLCH/USP). Bacharel em Ciências Sociais e mestre em Ciência Política pela Faculdade de Ciências Sociais da Universidade Federal de Goiás (PPGCP/FCS/UFG). E-mail: sergiombk@gmail.com. 
people who stood out in the debate as Hanna Pitkin, Bernard Manin and Nadia Urbinati. After that I highlight some empirical studies on the dynamics of democracies today, citing the works of authors such as Peter Mair, Roberto Foa

and Yascha Mounk, and more specifically I deal with democracy in contexts of neoliberalism and austerity policies, based on the writings of Colin Crouch, Donatella della Porta and Wendy Brown - among others like Colin Hay, who dealt with the phenomenon of depoliticization. The result of this exercise, from a standpoint informed by fiscal sociology, is that at least the classic works of representation theory leave in the background the growing asymmetry between representatives and those represented, and the high inequality between citizens. Thus, I suggest that it is necessary to bring these aspects to the foreground, to consider the political, economic, and social context in which the representation process unfolds.

Keywords: Democratic theory; Crisis of democracy; Fiscal Sociology; Political economy; Political representation.

\section{Resumen}

Representación política en contextos de neoliberalismo y austeridad: posibles contribuciones analíticas a partir de la sociología fiscal

Con referencia a la teoría política y estudios empíricos acerca del desempeño de las democracias contemporáneas, este artículo tiene por objetivo evaluar el hipotesís de la crisis de representación bajo una perspectiva informada por la economía política. En un primer momento, presento a una revisión de la literatura dedicada a representación política, mencionando a los principales nombres que marcan el debate como Hanna Pitkin, Bernard Manin e Nadia Urbinati. Adelante, subrayo algunos estudios empíricos sobre la dinámica de las democracias en la atualidad, acudimos a las obras de autores como Peter Mair, Roberto Foa e Yascha Mounk, y más específicamente trato acerca de la democracia en contextos de neoliberalismo y políticas de austeridad, basándonos en los escritos de Colin Crouch, Donatella della Porta e Wendy - y otros, tal cual Colin Hay, que abordan el fenómeno de la despolitización. Lo que resulta de este ejercicio, desde una perspectiva informada por la sociología fiscal, es que al menos las obras clásicas de la teoría de la representación dejan en según plano la creciente asimetría entre representantes y representados y un alto nivel de desigualdad entre ciudadanos y ciudadanas. De esa manera, sugiero que es necesario traer esos aspectos al primer plano, teniendo en cuenta el contexto político, económico y social en que se desarrolla el proceso de la representación.

Palabras-clave: Teoría democrática; Crisis de la democracia; Sociología fiscal; Economía política; Representación política. 


\section{Introdução ${ }^{2}$}

Desde a crise econômica eclodida em 2008, em especial, é possível observar um crescente descrédito das instituições e da classe política nas democracias ocidentais (SCHAFER; STREECK, 2013). Entre 2011 e 2013 ocorreu uma onda global de protestos (FOMINAYA, 2014), compreendendo países como Estados Unidos, Portugal, Espanha, Grécia, Turquia e Brasil, que tinha como principais alvos os governos nacionais e seus sistemas político e econômico - manifestando, em linhas gerais, críticas à efetividade da democracia, da representação política e contra medidas de ajuste fiscal e austeridade (ORTIZ et al., 2013). Nesse contexto, alguns pesquisadores apontam um afastamento dos cidadãos e cidadãs da política convencional, evidenciado nos países do Norte, entre outras variáveis, por baixas taxas de comparecimento eleitoral, alta volatilidade, baixa identificação partidária e vínculo formal com partidos políticos - concomitante à busca de outras formas de atividade política e de representação em outros espaços, como organizações não-governamentais e grupos de interesse (HAY, 2007; MAIR, 2013).

Feita esta contextualização, e diante dessas evidências, este trabalho busca averiguar uma amostra da literatura recente da ciência política, referindo-se a trabalhos tanto teóricos como empíricos, de modo a avaliar como a representação política foi definida e examinada, e a maneira como ela se concretiza no atual contexto político, econômico e social. Relacionando esse problema com a hipótese da crise de representação nas democracias contemporâneas busco, ainda que brevemente, evidenciar como a teoria política da representação pode se beneficiar ao incorporar elementos da economia política e a própria questão da fiscalidade do Estado.

\footnotetext{
2 Uma versão preliminar deste artigo foi apresentada no V Fórum Brasileiro de Pós-Graduação em Ciência Política (V FBCP) ocorrido em Teresina-PI, julho de 2017. Um agradecimento especial ao professor Francisco Tavares por ter acompanhado e estimulado a sua escrita na disciplina "Estado e democracia na era da austeridade: estudos avançados em teoria democrática contemporânea e sociologia fiscal" (Programa de Pós-Graduação em Ciência Política, Universidade Federal de Goiás, 2016), no período em que se gestava o Grupo de Estudos e Pesquisas Socio-Fiscais (GESF/UFG). Além disso agradeço pelos comentários das pareceristas, que foram muito importantes para esclarecer e reforçar alguns pontos, além daqueles que me foram encaminhados pela professora Vera Cepêda, o professor João Botelho, e as (os) colegas Eveline Martins, Germano Coelho, Rayanne Araújo, e Wilton Barbosa. Naturalmente, possíveis imprecisões e lacunas são de minha responsabilidade.
} 
A pergunta que guia este estudo é se a partir das definições apresentadas na literatura seria possível identificar um esvaziamento da atividade representativa nas democracias contemporâneas. Presume-se que tal fenômeno seria mais significativo num contexto de crise fiscal dos Estados, como sinaliza o atual e crescente descolamento ou afastamento entre a população em geral e a classe política - que produziu efeitos na atuação desses atores. Dessa maneira busco sustentar que a hipótese da crise de representação, antes de ser suplantada, merece no atual contexto um tratamento analítico que incorpore de alguma maneira o conhecimento da economia política dos Estados - e mesmo questões relativas ao que se definiu na literatura como Estado tributário (SCHUMPETER, 1991 [1918]), considerando a sua importância para uma compreensão mais ampla da política democrática. Veremos que a teoria da representação, ainda que há muito ciente do problema das desigualdades, não o colocou em primeiro plano em suas considerações teóricas, renegando um elemento que se apresenta como essencial para compreender a atual dinâmica da representação.

Trata-se de um objetivo modesto, em um argumento teórico empiricamente fundamentado a partir da produção acadêmica disponível e relevante no que se refere à temática. Adoto como pressuposto que as questões discutidas, tanto referente à representação política quanto a respeito das bases fiscais do Estado, são de fundamento para a operação das comunidades políticas modernas. Busco então acompanhar a tensão entre política e economia nas diferentes vertentes da teoria democrática contemporânea elencadas, e seus limites. O necessário recorte da realidade para tratamento do tema em um artigo como este, quando direcionado a aspectos institucionais e a participação política formal, não exclui nem menospreza outras formas de ativismo político inerentes a uma democracia, normativamente e da forma como entendo, pujante e saudável ${ }^{3}$. Já argumentei em outra ocasião (BENEDITO, 2019) como o núcleo conceitual do minimalismo é insuficiente para dar conta do funcionamento da democracia, e de fato se amplifica no curso dos processos políticos. Por isso, não se

\footnotetext{
${ }^{3}$ Uma pertinente abordagem da relação entre política convencional e movimentos sociais, em contextos de austeridade, pode ser encontrada em Kriesi (2016).
} 
poderia dispensar a dimensão normativa, e a valorização dos direitos e das liberdades de opinião e participação política - antes relegados por autores como Schumpeter e Downs. Ao recorrer aos escritos destes dois últimos autores mais a frente restará claro que, mesmo sob um entendimento restrito da democracia, se a política fiscal é colocada além da alçada da cidadania em um determinado regime então este pouco possui de democrático - diagnóstico este que não impede a possível consideração de outras variáveis.

Inicialmente apresentarei uma abordagem teórico-conceitual sobre a representação fundamentada em alguns dos autores e autoras considerados canônicos no tratamento do tema como Pitkin (1967), Manin (1997) e Urbinati (2006). A partir da síntese dos argumentos e posterior crítica dessas diferentes concepções levantarei, a partir da sociologia fiscal, aspectos importantes a serem considerados no que se trata da representação - de modo a fundamentar a concepção adotada na análise subsequente. Adiante examinarei alguns trabalhos empíricos (MAIR, 2009; 2013; FOA; MOUNK, 2016; 2017) que trataram sobre a atuação dos partidos políticos, democracia e representação na atualidade. Tais considerações serão cotejadas posteriormente com trabalhos que buscaram caracterizar o funcionamento das democracias em contextos de neoliberalismo e aplicação de medidas de austeridade nas democracias do Norte global. Nesse momento serão úteis os apontamentos de autores e autoras como Crouch (2004) e seu conceito de pós-democracia, della Porta (2015), crise de responsabilidade, e Brown (2015) sobre os efeitos do neoliberalismo e sua subjetividade sobre a democracia. Igualmente, explorarei alguns aspectos do conceito de despolitização, tratado por autores como Hay (2007), Wood e Flinders (2014) e Burnham (2001). Enfim, nas considerações finais buscarei realizar alguns breves apontamentos relacionados à temática proposta e uma possível agenda de estudos da representação política, a partir dos temas discutidos, no que se refere ao Brasil - ainda que o texto se concentre no contexto do Norte, sem pretensões de generalização, dadas as diferenças entre os países dos dois hemisférios. 


\section{Representação Política}

É vasta a literatura política no que tange ao conceito e a prática da representação nas democracias contemporâneas. Mais recentemente, autores e autoras como Anne Phillips (1998), Andrew Rehfeld (2006), Iris Marion Young (2002), Jane Mansbridge (2003), Michael Saward (2010), Dario Castiglione e Mark Warren (2019 [2006]), para mencionar apenas uma ínfima parcela, dedicaram-se a discutir os diferentes aspectos da representação política. Esses tópicos se referem, por exemplo, às instituições representativas e sua conformação, ao perfil e papel dos representantes, às formas de participação popular e os diferentes meios pelos quais as pessoas se fazem representar - não apenas pelo parlamento, mas por movimentos sociais, sindicatos, organizações não-governamentais, entre outros - e ao que se poderia compreender como uma representação política legítima de fato - a relação entre representantes e representados 4 .

Seja qual for a abordagem adotada, observa-se um relativo consenso sobre as pessoas e as obras que marcaram as discussões nas últimas décadas. Não sendo o objetivo deste trabalho esgotar a controvérsia sobre o conceito de representação, busco me referir nesta parte aos principais autores e autoras que balizaram o debate, de forma a esclarecer nuances quanto ao conceito a serem abordadas na análise posterior. Conforme exposto a seguir, Hanna Pitkin (1967) oferece as categorias convencionais, posteriormente ampliadas e mesmo criticadas em outras apreensões teóricas do conceito $^{5}$, para o debate contemporâneo sobre representação, quando apresenta as perspectivas formalística, descritiva, simbólica e substantiva. Bernard Manin (1997), ainda que não se concentre da mesma forma sob o conceito em si, trata sobre a representação em seu caráter dinâmico na história, caracterizando, por meio de seus

\footnotetext{
${ }^{4}$ Para uma visão geral sobre essa linha de estudos, conferir Dovi (2017). Para uma abordagem mais ampla sobre democracia e representação, ver Miguel (2014).

${ }^{5}$ A representação descritiva, por exemplo, serviu de base para a crítica da diminuta presença (ou exclusão) de "mulheres, trabalhadores e minorias étnicas... nos espaços de poder" (MIGUEL, 2014, p. 117), desafiando perspectivas que consideram esse elemento irrelevante. Para uma crítica do paradoxo entre presença e ausência, segundo a definição de representação postulada por Pitkin, confira-se Plotke (1997). Seu argumento de que o contrário da representação não é participação, e sim exclusão, seria aprofundado por Urbinati em seus escritos, como veremos a seguir.
} 
princípios, o que pode ser entendido como um governo representativo em diferentes contextos. Por fim, Nadia Urbinati (2006b) realiza um estudo teórico correlato ao de Pitkin, mas chega a conclusões mais profundas sobre a relação entre democracia e representação, desafiando as concepções anteriores ao tratar essa última como um processo político. Assim, ainda que com limites que serão apontados oportunamente, justifica-se a escolha realizada pela representatividade e difusão de suas ideias na literatura correspondente (DOVI, 2017), que serão úteis para uma apreensão qualificada da representação política nas democracias contemporâneas. A seguir, apresento uma breve síntese e crítica de suas ideias, seguida de uma tentativa de contribuição para que o conceito tenha um tratamento mais amplo.

\section{$O$ conceito de representação}

A obra seminal de Hanna Pitkin (1967) é considerada como uma referência para o debate sobre a representação política. Nela, a autora apresenta uma análise conceitual, partindo dos significados atribuídos à palavra na história, até chegar ao que se entende por representação na contemporaneidade. Para isso, adota a perspectiva da filosofia da linguagem, em uma análise linguística com base em autores como J. L. Austin e Ludwig Wittgenstein. As questões fundamentais que guiam a obra dizem respeito a forma como as pessoas se entendem representadas: o que é necessário para dizer que uma pessoa é (se considere) representada? Assim, busca diferenciar a sua preocupação das possíveis causas psicológicas do que as pessoas entenderiam subjetivamente como representação. Além disso a obra se configura como um estudo da história do pensamento político, na medida em que dedica considerável espaço ao desenvolvimento da ideia de representação na história e como foi tratada por diferentes teóricos políticos como Thomas Hobbes, James Madison e Edmund Burke.

Em linhas gerais compreende-se que a ideia de representação tal como entendemos hoje é moderna. Ela tem se desenvolvido desde o século XVII, sendo que uma das mais precoces utilizações do termo se apresentou na obra De Republica Anglorum de Sir Thomas Smith em 1583, quando se referia ao parlamento inglês como 
representante da população naquele momento histórico (PITKIN, 1967). A representação popular veio a se delinear em especial no contexto das revoluções americana e francesa, em que se associou com a ideia de auto-governo, vínculada à conformação das instituições desde então. Tal desenvolvimento, contudo, não se deu sem controvérsias, relacionadas por exemplo ao direito de voto, o consentimento da população e a relação entre representantes e representados (mandato imperativo vs. independência). Em suma, a autora parte da premissa de que a representação possui um significado identificável, concebido de maneiras diversas em diferentes contextos; e que desde o assentamento dos ideais das revoluções mencionadas acima não ocorreram mudanças significativas em seu significado.

Pitkin (1967) compreende que o conceito de representação encerra um paradoxo. Fundamentando-se em interpretação de vários comentadores, considera que a representação pode ser entendida como 're-presentar', tornar presente novamente; e ao se dizer que algo se faz presente ao mesmo tempo que se encontra ausente, apresenta-se um dualismo fundamental ao significado do conceito. "Podemos dizer simplesmente que na representação algo que não está literalmente presente é considerado como presente em um sentido não literal" (PITKIN, 1976, p. 9, tradução livre). Daí provém toda a controvérsia a respeito do papel dos representantes e sua relação com os representados e as diferentes perspectivas que podem ser adotadas para caracterizar a representação. Encaminhando sua análise, a autora identifica quatro possíveis interpretações: representação formalística (nas dimensões de autorização e accountability), descritiva, simbólica e substantiva.

A representação formalística se preocupa em grande medida com o arranjo institucional por meio do qual a representação se realiza. Em sua dimensão de autorização, concentra-se sobre a maneira como o representante obtém ou chega ao cargo, reservando toda a liberdade às suas ações. A segunda dimensão, accountability, foca em especial na possibilidade de os representados punirem os representantes caso esses não levem em consideração seus desejos e preferências. Contudo, resta ainda a impossibilidade de prescrever suas ações. Logo, em ambas não se revelam critérios evidentes para avaliação das ações levadas a cabo pelos governantes. A representação descritiva compreende a semelhança dos representantes com relação aos 
representados no que se refere a ideais, interesses, entre outras características; nesse caso a avaliação do representante se concentra somente no que ele é, o quanto ele se aproxima de seus representados, e não em suas ações. Já a representação simbólica se refere à imagem pública que o representante possui entre seus representados; importa aqui a aceitação, o convencimento e a manutenção de um vínculo baseado na estima.

Argumentando que nenhuma dessas perspectivas oferece a possibilidade de avaliar a prática da representação como uma atividade para, em nome, no interesse ou como agente de outras pessoas, Pitkin (1967) propõe uma quarta interpretação (que ela adota nos capítulos finais de sua obra): a representação substantiva. Trata-se de uma maneira de enfatizar os critérios pelos quais podemos julgar as ações e a performance de um representante, já que nenhuma das perspectivas anteriormente apresentadas oferece subsídios para que se pense em um padrão de conduta relacionado à ideia de representação - a conduta do representante "permanece irrelevante" (PITKIN, 1967, p. 113). Uma perspectiva substantiva da representação permite que a própria pessoa compreenda o que se exige do cargo e o seu papel enquanto representante, algo que é apenas implícito nas interpretações descritiva e simbólica. "O fato de que um homem, ou uma assembleia, sejam uma ótima representação descritiva não garante automaticamente que eles serão bons representantes no sentido de agir para, e que sua atividade será realmente representativa" (PITKIN, 1967, p. 142, tradução livre, grifo meu). Para que se possa falar em representação, portanto, é necessário, por um lado, que o representante seja responsivo aos representados; por outro, que as ações do representante possam ser atribuídas aos representados.

Em suma a representação, segundo essa perspectiva, significa atuar de acordo com os interesses de seus representados, ainda que o representante mantenha (deva manter) a sua independência de ação e julgamento. Tal definição abre margem para possíveis divergências sobre as melhores decisões políticas. Contudo, segundo Pitkin (1967, p. 209, tradução livre), “o representante deve agir de tal maneira que não exista conflito ou, caso ocorra, uma explicação se faz necessária". Desde que exista uma boa razão para explicar o motivo pelo qual as preferências dos representados "não estão em acordo com seus interesses" (PITKIN, 1967, p. 210), a representação pode ser efetivada 
sem constantes conflitos. O raciocínio se fecha com a seguinte colocação: "O sistema representativo deve cuidar do interesse público e ser responsivo à opinião pública, exceto na medida em que a não-responsividade possa ser justificada em termos do interesse público" (PITKIN, 1967, p. 224, tradução livre). Tais definições, por um lado, podem implicar que o representante sabe quando é mais conveniente tomar uma ou outra conduta política, contrastando com passagens em que Pitkin enfatiza que a política não é uma 'ciência exata' ou uma questão de puro conhecimento (PITKIN, p. $137 ; 212)$. Por outro, revelam um aspecto que, ainda que reconhecido, foi deixado em segundo plano em estudos sobre representação posteriores, no que diz respeito, se não aos meios dos quais dispõem os representantes quando assumem seus cargos - que ampliam suas capacidades -, ao fato de que os representantes participam "da confecção da agenda pública" interferindo na formação das preferências (e julgamentos) da cidadania em geral (MIGUEL, 2014, p. 121).

Essas implicações tornam-se ainda mais complicadas ao se ter em conta a atual conjuntura política, econômica e social em que se dá a prática da representação. Em poucas palavras, compreende-se da leitura exposta acima que Pitkin pouco se engajou naquele momento em considerações sobre o contexto econômico em que se realiza a representação ${ }^{6}$, o que obscurece, por um lado, a importância da conformação do Estado moderno como um Estado tributário77 (SCHUMPETER, 1991) e, por outro, a significativa influência de determinados grupos econômicos e de interesse na política convencional - que redunda em desigualdade política entre cidadãos e cidadãs. Como será melhor exposto na conclusão desta seção, e em maior profundidade na terceira parte do artigo, existe uma tensão fundamental entre democracia e capitalismo (STREECK, 2017 [2014])

\footnotetext{
${ }^{6}$ Justiça seja feita, a própria Pitkin (1967) comunica no início da introdução que sua obra se dirige exclusivamente à análise conceitual da representação. Como exposto, contudo, entendo que a prática da representação deve ser avaliada em um determinado contexto, e a abordagem da autora abre pouca margem para pensar as desigualdades e assimetrias de poder de fundo econômico.

${ }^{7}$ Em poucas palavras Tax state, Estado tributário, ou Estado fiscal no trabalho de autores como Streeck (2017), caracteriza para Schumpeter (1991) a forma madura do Estado após os regimes feudais. Sua constituição marca o estabelecimento do Estado soberano em que, para a realização de suas atividades fundamentais, há uma racionalização da arrecadação de recursos para o seu financiamento, com o consentimento de suas populações. Acompanha, por isso, a formação das sociedades liberais burguesas e do próprio capitalismo. A política fiscal contempla tanto a arrecadação quanto o dispêndio de recursos, daí sendo possível deduzir a sua relação com a política democrática. Sobre a relação entre tributação e democratização em diferentes períodos históricos, confira-se Tilly (2009).
} 
que implica, por parte dos representantes e em certos momentos, uma escolha entre responsabilidade - aderência às regras, leis e compromissos assumidos com determinadas agências e instituições - e responsividade - atendimento às demandas colocadas pela população, em políticas que contemplem seus interesses mais amplos e duradouros (MAIR, 2009). Percebemos, por conseguinte, como a responsividade postulada por Pitkin é mais complicada de se realizar do que parece à primeira vista, e que os representantes possuem meios para contornar a necessidade de prestar contas ou mesmo para convencer a população de que certas medidas são 'necessárias', gerando uma crise de responsabilidade (DELLA PORTA, 2015). Ainda que este último ponto tenha sido melhor reconhecido e tratado na literatura posteriormente, chamo atenção para sua pertinência e a necessidade de que ele ganhe proeminência ao se tratar sobre a prática da representação nas democracias do século XXI.

\section{Os princípios do governo representativo e sua metamorfose}

Em sua obra Os princípios do governo representativo, Bernard Manin busca realizar uma análise do desenvolvimento histórico do governo representativo (ou do que se entende por essa forma de governo em cada contexto). Para isso, identifica elementos que se mantiveram constantes desde os séculos XVII e XVIII, os quais denomina princípios ${ }^{8}$. Não se trata, quanto a esses últimos, de ideais abstratos ou ideias imemoriais mas de "arranjos institucionais concretos que foram inventados em um ponto particular da história e que, desde aquele momento, têm sido observados como simultaneamente presentes em todos os governos descritos como representativos" (MANIN, 1997, p. 4, tradução livre). A questão que perpassa a obra não é sobre o significado de democracia, ou mesmo do termo representação, mas o nexo desses princípios com os elementos que compõem a ideia de democracia e as consequências de uma determinada combinação de arranjos institucionais sobre a política de um

\footnotetext{
${ }^{8}$ Importante frisar que grande parte das considerações do autor sobre o governo representativo se referem em especial à Europa (Inglaterra, França) e Estados Unidos.
} 
determinado local e contexto. Assim, o autor identifica quatro princípios que seriam comuns aos governos representativos: 1) Os representantes são eleitos pelos governados em intervalos regulares; 2) Os representantes conservam uma independência parcial diante das preferências do eleitorado; 3) Os governados podem expressar suas opiniões e preferências independentemente do controle do governo; 4) As decisões políticas passam por (são tomadas após) um debate público (cf. MANIN, 1995).

No que se refere à conformação desses princípios, histórica e politicamente, é necessário colocar em relevo alguns pontos centrais. Manin (1997) salienta que a eleição, "a instituição central do governo representativo" (MANIN, 1997, p. 6, tradução livre), suplantou a opção pelo sorteio, indicando que desde a origem não se observava incompatibilidade entre representação e governo 'dos melhores' - o caráter aristocrático do governo representativo desde a sua fundação é um ponto recorrente em sua obra. Percebemos então que esta forma de governo contém, ao mesmo tempo, uma dimensão democrática - os eleitores julgam os governantes por meio das eleições que, sendo periódicas, também influenciam o comportamento dos representantes - e outra não-democrática - pois nada obriga os governantes a considerarem as preferências dos eleitores. Dois outros elementos que não se firmaram foram o mandato imperativo (ou as instruções aos representantes) e a permanente revocabilidade dos cargos, o que indica que o princípio da independência sempre foi um ideal priorizado. Por outro lado, a liberdade de opinião apresentou-se como contrapeso à ausência de instruções dos representados, visto que os representantes não podem ignorá-los por completo; assim, reserva-se à população o direito de expressar-se e influir de alguma forma no governo, o que permite também a mobilização popular. Por fim, o legado histórico da assembleia como espaço de debates influenciou a prática da representação na era moderna, manifestando-se na ideia de governo pela discussão. No princípio, contudo, a função do debate era mais de produzir acordo e consenso do que um fundamento para a tomada de decisões. Em suma, considerados esses elementos em conjunto, para Manin “a democracia representativa não é uma forma indireta de governo pelo povo... mas um sistema em que políticas públicas e decisões estão sujeitas ao veredito do povo" (MANIN, 1997, p. 192, tradução livre). 
A partir dos princípios anteriormente abordados o autor elabora três tipos ideais, referentes à conformação do sistema político, de modo a comparar e analisar suas peculiaridades em cada contexto: democracia parlamentar, de partido, e de audiência (ou do público). Me detendo em especial sobre este último, trata-se de uma transformação da democracia de partido ocorrida nas últimas décadas. Nela, a escolha eleitoral se dá cada vez mais por aspectos pessoais dos candidatos: por um lado, com a popularização da televisão, os candidatos passaram a se expressar diretamente ao eleitorado, enfatizando suas qualidades pessoais; por outro, com a complexificação dos assuntos políticos, tornou-se comum o ato de se esquivar do debate e alienar as decisões de governo aos candidatos vistos como 'melhor preparados' para agirem discricionariamente em tempos de imprevisibilidade. Mudou, enfim, o perfil das elites selecionadas a governar: do ativista político e do burocrata de partido ao comunicador profissional (cf. MANIN, 1997, p. 220). Além disso, as disputas são decididas mais frequentemente por fatores contextuais, sobre "o que está em jogo em uma eleição particular... Os eleitores parecem responder (a condições particulares oferecidas em cada eleição), mais do que apenas expressar (suas identidades social ou cultural)" (MANIN, 1997, p. 222, grifos no original, tradução livre). Esse elemento é essencial para definir a democracia de audiência, já que os representantes agora cumprem o papel de identificar clivagens sociais e expor ao eleitorado os termos da escolha - no que se refere aos temas ou 'pacotes de propostas'.

Da mesma forma, os demais princípios são influenciados pela mudança no caráter da opinião pública. Considerando que os candidatos são eleitos com base em imagens difusas, e que os eleitores não possuem conhecimento especializado para avaliar suas propostas, os representantes adquirem um grau de liberdade - ou discricionariedade, em seus termos - ainda maior. Na democracia de partido existia um alinhamento entre opinião pública e expressão eleitoral - devido à concentração dos meios de comunicação pelos partidos. Já na atualidade, com as mídias atuando de maneira independente e produzindo informações neutralizadas e iguais a todos, as diferentes opiniões daí advindas podem não encontrar correspondência nas clivagens eleitorais retornando ao que se verificava na democracia parlamentar. Por fim, o parlamento 
continua não representando um espaço de discussão, já que os partidos tendem a seguir, de forma disciplinada, as orientações de sua liderança. Os parlamentares, individualmente, podem estabelecer diálogo com grupos de interesse de forma a orientar sua atuação, mas a característica mais evidente aqui é sua tentativa de buscar a atenção do público enquanto as medidas são votadas no parlamento, apelando ao eleitor 'flutuante' com suas capacidades comunicativas.

Fundamentado na interpretação exposta sinteticamente acima, Manin defende a tese de que não se conforma na atualidade uma 'crise de representação'. A sensação que temos hoje não seria muito diferente daquela apresentada por autores como Ostrogorski ${ }^{9}$ na virada do século XIX para o XX, quando começava a se conformar a democracia de partido. O governo representativo sempre teve um caráter aristocrático e o que mudou ao longo da história foi apenas o tipo de elite que é eleita. "Mais do que a substituição de uma elite por outra, é a persistência, possivelmente até o agravamento, da lacuna entre os governados e a elite governante que tem provocado uma sensação de crise" (MANIN, 1997, p. 233, tradução livre). O autor conclui a obra destacando que, apesar de tudo, os eleitores continuam influindo de alguma forma no governo, seja pela liberdade de opinião e manifestação, seja pelo poder de retirar os representantes do cargo pelo voto - todos os cidadãos têm "um igual poder para designar e destituir seus governantes" (MANIN, 1997, p. 238, grifo meu, tradução livre). Restam dúvidas, contudo, sobre em que medida esse poder se faz efetivo na democracia de audiência. Mais que isso, ao não dar substantiva ênfase ao contexto socioeconômico em que se dão as relações entre representantes e representados, Manin subestima a significativa desigualdade existente entre esses grupos ${ }^{10}$. Em poucas palavras, é preciso considerar também a conformação do Estado em que se constitui um governo

\footnotetext{
${ }^{9}$ Moisei Ostrogorski (1854-1921) foi um cientista político de origem russa que tratou longamente sobre o sistema político americano e inglês em perspectiva comparada, criticando a adaptação da democracia centrada nos partidos. Influenciou sobremaneira a obra de autores como Robert Michels e Max Weber. ${ }^{10}$ Em uma obra posterior Manin, em parceria com Przeworski e Stokes (2006), reconhece (entre outros) alguns problemas relacionados a doações corporativas e empresariais (que teriam o efeito de distorcer a competição eleitoral) e a possibilidade de que a classe política se esquive de suas responsabilidades frente ao eleitorado (quando direcionam benefícios a si próprios, suas famílias e clientelas). Essa abordagem, ainda que meritória, segundo o raciocínio construído neste artigo ainda fica aquém de um entendimento estrutural e de longo prazo da conformação das desigualdades societárias que possuem efeito na possibilidade de exercício político da cidadania por diferentes meios (institucionais ou não).
} 
representativo - pressuposto ausente em sua análise. Por fim, resta o problema mencionado anteriormente sobre o poder dos incumbentes - ainda que Manin reconheça o potencial de formação da agenda pública por parte dos representantes. Retornaremos a essas questões no fechamento dessa seção.

\section{A representação do ponto de vista do processo político}

Nadia Urbinati (2006b) toma uma direção confluente com a de Pitkin e muito diversa de Manin em Democracia representativa: princípios e genealogia. Por um lado, está preocupada em analisar as origens, funções e transformações da representação em termos semânticos e políticos, observando seu nexo com a forma constitucional democrática. Por outro, dedica uma considerável parte de sua obra para defender a tese de que democracia e representação são complementares e se reforçam: a representação não é uma alternativa à democracia direta, um 'mal menor' em vista das restrições à participação existentes nos Estados modernos. Trata-se, com efeito, de um mecanismo que fomenta uma sociedade pluralista, em que a política se desenvolve pelo julgamento das condutas de governo e do debate de ideias, em que diferentes grupos buscam apresentar suas concepções políticas. Nesse sentido, portanto, contrapõe-se a concepções de governo representativo que enfatizam elementos democráticos e nãodemocráticos - uma interpretação derivada de autores do século XVII e XVIII, segundo a autora -, e também àqueles que entendem que a democracia se realiza apenas nas eleições. Compreendendo a representação como processo Urbinati busca enfatizar os aspectos que compõem o cerne normativo do conceito.

Percebemos então o seu alinhamento com concepções liberais e pluralistas da sociedade política, por sua ênfase na capacidade, e na moralidade, das pessoas possuírem e expressarem diferentes opiniões e julgamentos. Urbinati parte do pressuposto de que a democracia representativa tem apresentado, de maneira geral, uma "performance de sucesso" (2006b, p. 18) e que parecem contraditórias as percepções apresentadas na literatura política a respeito dos elementos elitistas de tal forma de governo. Recorrentemente esses autores e autoras pressupõem que 
democracia de fato acontece somente de forma direta, e que a representação não é um substituto válido. A autora, contra Rousseau, busca reabilitar o conceito de representação dando conta do "processo circular (suscetível ao atrito) entre as instituições estatais e as práticas sociais" (URBINATI, 2006a, p. 192), diferente da democracia direta que se esgota em cada manifestação da vontade. Nesse contexto, "as opiniões e as crenças podem converter o poder em um processo político incessante ao qual a representação dá efetividade, pois enaltece o mundo público das ideias e a mediação do discurso" (URBINATI, 2006a, p. 213).

Em sua análise sobre o conceito são apresentadas três perspectivas da representação a partir da teoria política: jurídica, institucional e política. Tais vertentes teóricas pressupõem fundamentos diversos sobre a soberania, o entendimento da política e a relação entre Estado e sociedade; além disso, podem ser reconhecidas, em especial, nas obras de Rousseau, Sieyes e Condorcet (URBINATI, 2006b). As duas primeiras se fundamentam "em uma analogia Estado-pessoa e em uma concepção voluntarista da soberania", sendo também "formuladas em linguagem formalista"; por este motivo a autora trata essas perspectivas de uma maneira muito próxima - a jurídica é anterior à institucional, já que precede "a moderna concepção do Estado soberano e a designação eleitoral de legisladores" (URBINATI, 2006b, p. 21, tradução livre). A teoria jurídica considera a representação como um contrato, uma espécie de procuração por meio da qual o representante possui licença para agir por um grupo de pessoas. Ademais, compreende a relação entre representantes e representados segundo uma “lógica individualística e não-política, na medida que pressupõe que os eleitores julgam as qualidades pessoais dos candidatos ao invés de seus projetos e ideias políticas" (URBINATI, 2006b, p. 22, tradução livre). Percebe-se assim que esta última perspectiva centra-se numa clara divisão entre Estado e sociedade e garante autonomia de ação ao representante, restringindo a participação dos cidadãos a um ato - a autorização, a eleição. A teoria institucional, tendo se desenvolvido posteriormente, pode ser entendida a partir do clássico modelo minimalista de democracia, com grande ênfase nos arranjos legais em detrimento da participação e expressão da identidade social das pessoas - mais uma vez, assegurando independência entre a esfera política e a esfera social. 
A perspectiva política da representação é a que Urbinati almeja não apenas elucidar, mas defender em sua obra. Segundo essa concepção, a representação deve ser entendida dinamicamente, em uma forma de existência política criada pelos próprios atores e atrizes: "a representação não pertence apenas aos agentes governamentais ou instituições, mas designa uma forma de processo político que é estruturada em termos da circularidade entre instituições e sociedade" (URBINATI, 2006b, p. 24, tradução livre). A política, assim, não se encerra no ato de autorização/eleição, mas está em constante (re)construção por meio de uma "corrente comunicativa entre sociedade civil e política". A autora enfatiza em especial o papel da voz e do julgamento realizado por cidadãos e cidadãs de forma a influenciar o governo e seus representantes, "tornando o social político" (URBINATI, 2006b, p. 24, tradução livre). Dois aspectos são essenciais à prática da representação: representatividade e advocacy: o primeiro como expressão do vínculo entre representantes e representados, que se manifesta em "relações de controle (por parte do representado) e de responsabilidade (por parte do representante) que são eminentemente políticas e morais, mas não jurídicas e legais" (URBINATI, 2006b, p. 50, tradução livre); o segundo entendido como a justaposição de dois componentes: adesão à causa dos representados - "o vínculo 'apaixonado' com a causa dos eleitores" - e independência de atuação - "autonomia de julgamento dos representantes" (URBINATI, 2006b, p. 45). As noções de representatividade e advocacy são centrais em sua obra posto que estruturam o que se considera um governo representativo de fato, em sua concepção - um governo em que seja possibilitada a autonomia de atuação de representantes e representados, conforme exposto acima. Por tudo isso, tais categorias desafiam interpretações anteriores do conceito (e da prática) de representação.

Não se pode menosprezar o mérito, o impacto e as contribuições de Urbinati nessa obra que marcou lugar no debate mais recente, carregando um grande potencial de crítica à representação 'realmente existente'. Contudo não foi esse o seu propósito em Democracia representativa, que se deteve mais ao 'dever ser' do que um cotejamento entre ideal e prática. Para além dos aspectos destacados a partir de Pitkin e Manin, nem mesmo a questão sobre a possibilidade de efetivação do modelo de 
cidadania que sua teoria implica, que exigiria um Estado com grande capacidade ${ }^{11}$ e uma considerável igualdade material entre cidadãos e cidadãs, é abordado pela autora. Mais recentemente Urbinati reconhece, contudo, que a democracia tem passado por mudanças que desafiam o conjunto de proposições por ela colocados em sua obra fundamental. Por um lado, no texto de uma conferência, relacionada ao seu livro Democracia desfigurada, ela expõe como a democracia tem deixado de ser um sistema político em que as pessoas em geral se envolvem e discutem temas relacionados à política, sendo seduzidas pela imagem e pelo desejo de lideranças fortes, o que leva mais recentemente ao fenômeno (ou ressurgência) do populismo (URBINATI, 2013). Por outro, numa entrevista realizada em conjunto com Manin, destaca que a 'democracia de audiência' é uma interpretação relevante, mas que se opõe ao que se espera de um governo de fato representativo (LANDEMORE, 2016). Isso demonstra que não é sem fundamento a crescente inquietação quanto ao que se tornou a representação política e quanto ao destino da democracia na contemporaneidade. Faz-se pertinente, por isso, tratar sobre a ideia de representação com referência ao contexto político, econômico, social e histórico no qual nos encontramos.

\section{Elementos para uma extensão do conceito}

A partir da síntese dos argumentos das obras apresentadas nessa seção, é possível retirar algumas conclusões que encaminham uma compreensão mais ampla sobre a representação. Pitkin (1967) apresenta um conceito que, apesar de reconhecer a responsividade dos representantes aos representados como fator importante, mantém uma margem considerável de discernimento aos primeiros, minando o papel do conflito, da participação e influência dos e das cidadãs na política. Manin (1997), por outro lado, elabora uma teoria política da representação que possui como ponto de partida os aspectos democráticos e não-democráticos do governo representativo. Contudo, ao atribuir tamanha importância às eleições e à liberdade de expressão como contrapesos

\footnotetext{
${ }^{11}$ A partir de Holmes e Sunstein (1999) entende-se que todos os direitos são positivos e demandam recursos e atenção das instituições estatais para que sejam efetivos. Para uma discussão sobre a capacidade dos Estados na garantia das instituições democráticas, cf. Tilly (2007).
} 
ao aspecto elitista da representação, acaba por diminuir a ênfase nas crescentes capacidades dos representantes - como participantes no processo de construção da agenda pública e sua influência na formação das preferências dos e das cidadãs (MIGUEL, 2014; cf. MANIN; PRZEWORSKI; STOKES, 2006, p. 121), favoráveis à manutenção do status quo. Finalmente, Urbinati (2006b), por seu entendimento da representação política como processo, calcado nas noções de representatividade e advocacy, oferece subsídios para uma crítica da prática representativa na atualidade. Entretanto, a estrutura de sua teoria, dada a perspectiva adotada, não enfatiza suficientemente a possível desigualdade de condições entre representantes e representados. Tomando essas contribuições em conjunto, se é possível interpretar que o desenvolvimento histórico da representação se deu por uma relativa aproximação entre representantes e representados com a ampliação do sufrágio na primeira metade do século XX (cf. PRZEWORSKI, 1989), acompanhada de uma aspiração democrática em geral, hoje os primeiros podem estar preponderando severamente e em favor de poderosos interesses minoritários, o que compromete a estabilidade dos governos democráticos.

Por essas razões, tanto para os estudos teóricos sobre representação em geral quanto para a análise posterior, propõe-se a relevância de uma noção de representação que coloque em primeiro plano as assimetrias presentes na sociedade e a potencial desigualdade não apenas entre representantes e representados, mas também entre as próprias pessoas representadas - o que influi no funcionamento da política e torna a representação menos democrática do que se pretende. Para isso, basta partir do fato de que, no Ocidente em geral, os Estados não são apenas democráticos mas capitalistas (STREECK, 2017), e que essa conformação interfere no caráter da representação política efetivada nesses territórios. Essa realidade já se colocava na época em que esses trabalhos canônicos foram elaborados e deveria ter sido considerada. Se reconhecemos, do ponto de vista da sociologia fiscal ${ }^{12}$, que o Estado moderno se constitui como Estado

\footnotetext{
${ }^{12}$ A sociologia fiscal foi inicialmente proposta como campo de estudos específico por Schumpeter (1991 [1918]), que tomou essa alcunha da obra do sociólogo Rudolf Goldscheid (1870-1931), também austríaco e seu contemporâneo. Segundo Martin, Mehrotra e Prasad (2009, p. 14) as "questões clássicas levantadas
} 
tributário (SCHUMPETER, 1991) e que ao longo das últimas décadas, desde o fim dos anos 1960, o equilíbrio político das democracias ocidentais esteve sujeito às condições das finanças públicas - como efeito da tensão entre democracia e economia capitalista -, no atual contexto, com a prevalência da austeridade como política de Estado, é possível constatar mudanças significativas no caráter dos governos representativos (SCHAFER; STREECK, 2013). Para demonstrar isso, tratarei na seção seguinte sobre algumas dessas particularidades, relacionando tanto quanto possível a forma como se efetiva a representação política nas democracias contemporâneas com a crise fiscal dos Estados.

\section{A hipótese da "crise de representação"}

Desde a virada do século XXI desdobra-se um extenso debate sobre a reconfiguração da democracia no mundo pós-Guerra Fria. No final dos anos 1990, como lembra Mair (2013), existiu um grande interesse, não apenas da academia como de organizações internacionais como o Banco Mundial, em tratar sobre os diferentes sistemas democráticos que se constituíam na chamada terceira onda (HUNTINGTON, 1994) e sobre as possibilidades de reforma constitucional - em um contexto em que se apresentavam sinais de crescente indiferença e desconfiança por parte das pessoas na política democrática. Manin (1997), por sua parte, marcou posição em sua obra fundamental argumentando que o diagnóstico de uma suposta crise de representação era enganoso, conforme exposto acima. Mais recentemente, em 2007, o autor reiterou sua posição, alegando que não ocorrem "mudanças e tendências bem estabelecidas" que se apresentam "inconsistentes com as características constitutivas do objeto sob

por Schumpeter" foram "as bases sociais dos sistemas tributários, os determinantes do consentimento do pagador de impostos, e as consequências sociais e culturais da tributação". Se durante a maior parte da segunda metade do século XX esses temas permaneceram separados em estudos de área, hoje o interesse daqueles e daquelas que se vinculam ao campo da 'nova sociologia fiscal' está em elaborar estudos interdisciplinares que avaliam os fundamentos e as consequências econômicas, políticas, sociais e culturais dos sistemas tributários - que possuem ramificações também nas dimensões de desigualdade em classe, raça e gênero (MARTIN; MEHROTRA; PRASAD, 2009, p. 13-14). 
consideração, potencialmente ameaçando sua sobrevivência"13 (LANDEMORE, 2016, p. 149). Indo mais longe, no posfácio da edição alemã de sua obra, Manin (2007) apresentou diversos argumentos para rebater as teses de que uma crise de representação se justificaria pelo definhamento dos partidos - que continuam fortes, tanto na arena parlamentar como na eleitoral, tendo apenas mudado a sua forma de atuação - e pela generalização de práticas não-institucionalizadas de participação política - que, ao contrário do que se poderia pensar, não indica o desprestígio da democracia, mas possui o potencial de rejuvenescê-la. Enfim, conclui o raciocínio alegando que os representantes devem ser responsivos aos representados, mas que essa responsividade (ou o peso de suas preferências) não está determinada e comporta graus variados.

Como veremos a seguir, se tais afirmações poderiam ser questionadas logo no período em que foram publicadas, ficaram ainda mais difíceis de sustentar após a crise financeira mundial de 2008. Tornou-se mais evidente que os indícios apontados para uma possível crise de representação possuem efeitos mais amplos e duradouros sobre o sistema democrático. Elementos como o descrédito das instituições e da classe política, menor participação convencional, desinteresse ou indiferença por assuntos políticos, constituição de diversas organizações e grupos de interesse que cumprem funções representativas, mudanças na atuação de partidos (e representantes) e seu crescente afastamento da sociedade, quando considerados em conjunto, podem acarretar a corrupção dos princípios democráticos, mesmo aqueles colocados por Manin ${ }^{14}$. Não se pode descartar, ainda, que tais elementos estejam ligados à conformação política e econômica das democracias contemporâneas - com o recuo de

\footnotetext{
${ }^{13}$ Nessa ocasião, expressou que "a viabilidade do governo representativo estaria ameaçada se os cidadãos parassem sistematicamente de lhe cultivar interesse e parassem de tomar parte nas diferentes formas de ação política que se lhes oferecem. Tal não parece ser o caso" (LANDEMORE, 2016, p. 150).

${ }_{14}$ Urbinati apresenta um questionamento convergente com esta interpretação: “[...] Não seria a democracia de audiência uma violação do governo representativo? Na minha opinião, esta nova forma de cesarismo ou populismo é uma violação da democracia representativa. Uma identificação acrítica das massas com um líder eleito por uma campanha que ele manipulou através dos meios de comunicação é ainda uma violação dos princípios da democracia representativa. Na minha opinião, o surgimento da democracia de audiência é realmente problemático, até mesmo mais do que os motins." (LANDEMORE, 2016, p. 151).
} 
direitos e políticas de bem-estar social e a perda de confiança nos representantes que, independente do viés ideológico, pouco podem fazer para barrar esse movimento nas atuais circunstâncias. Quando a democracia deixa de ser "o único jogo disponível na sociedade" (LINZ; STEPAN, 1999, p. 23) para uma parcela significativa das populações dos países democráticos, é prudente contemplar a possibilidade de sua desconsolidação (FOA; MOUNK, 2017). Nas subseções a seguir tratarei, primeiro, sobre alguns estudos empíricos que fornecem evidências para avaliar a hipótese da crise de representação tal como apresentada acima; depois, mais especificamente, como a representação política tem se mostrado em contextos de neoliberalismo e austeridade.

\section{Partidos políticos, representação e democracia}

O cientista político Peter Mair (1951-2011) foi um dos grandes acadêmicos na linha de pesquisa relacionada a partidos políticos e sistemas partidários em perspectiva comparada. Um dos formuladores do conceito de partidos cartel ${ }^{15}$, esse autor estava em posição privilegiada para analisar as recentes alterações na relação entre partidos políticos, representação e governo democrático. Em sua última obra, publicada postumamente, Mair (2013, p. 1, tradução livre) dedicou-se a investigar o 'fim da era dos partidos', um cenário em que, mesmo existindo, "eles tornaram-se tão desconectados da sociedade mais ampla, e perseguem uma forma de competição tão frágil em significado, que eles não parecem mais capazes de sustentar a democracia em sua presente forma". Como já havia assinalado anteriormente (MAIR, 2009), os partidos têm minimizado seu papel representativo e maximizado o governativo, com efeitos inconvenientes na sua capacidade de mobilizar a sociedade e responder às preferências dessa última - consideradas as restrições do governo, como a necessidade de atender a

${ }^{15} \mathrm{O}$ conceito se refere àqueles partidos que se concentram em torno do Estado de modo a angariar recursos e cargos em detrimento da representação efetiva de cidadãos e cidadãs - por exemplo, ao eliminar diferenças substantivas entre os partidos na medida em que aderem a governos de coalizão, ou quando oferecem propostas de governo muito similares (KATZ; MAIR, 1995). Uma análise mais aprofundada sobre o conceito pode ser encontrada em Amaral (2013). 
diferentes interesses, agências e organizações, domésticas ou não ${ }^{16}$, e de efetivar a agenda colocada por governos anteriores, cumprindo leis e políticas sancionadas em mandatos pretéritos. Essa ênfase na responsabilidade em prejuízo da responsividade teve o efeito de afastar, concomitantemente, cidadãos e cidadãs da política para a vida privada "ou para formas mais especializadas e frequentemente mais imediatas de representação" (MAIR, 2013, p. 16, tradução livre). Nesse sentido, os partidos políticos estão fracassando e colocando em risco a própria democracia ${ }^{17}$.

Referindo-se a The Semi-Sovereign People, de E.E. Schattschneider, Mair (2013, p. 2, tradução livre) pontua que

"De fato, quase meio século depois, parece que mesmo a semisoberania está nos escapando, e que o povo, ou a cidadania comum, está se tornando efetivamente não-soberana. O que estamos vendo emergir agora é uma noção de democracia que está sendo constantemente despida de seu componente popular - afastando-se do demos."

Tais diagnósticos podem ser amparados na literatura que trata sobre o caráter das democracias na contemporaneidade (CROUCH, 2004; BROWN, 2015; DELLA PORTA, 2015); contudo, antes de iniciar esse diálogo, cabe explorar em mais detalhes a análise e os achados de Mair (2013). Inicialmente, o autor se utiliza de dados eleitorais de quinze países da Europa ocidental, entre as décadas de 1950 e 2000 (1950-2009), para

\footnotetext{
${ }^{16}$ Schafer e Streeck (2013, p. 19) referem-se a um ponto similar quando tratam sobre "the two constituencies of the austerity state", argumentando que em contextos de austeridade o governo presta contas não somente ao povo, mas também aos 'mercados'.

${ }^{17}$ Por certo, a classe política e os partidos tomam decisões como essas e adotam uma agenda política neoliberal às vezes com apoio da própria cidadania - e colhem resultados de curto prazo com isso, até as revoltas populares resultantes de seus efeitos. O que se afirma aqui é que essas escolhas possuem profundos e duradouros efeitos sobre a política democrática. Deduz-se isso, por exemplo, da obra de Hay (2007) que dá conta de como a política passou a ser uma palavra e uma prática detestável ao mesmo tempo que a classe política abraçava os princípios da teoria da escolha racional (que dão base ao ideário neoliberal). A esse respeito, a partir de uma perspectiva alternativa, confira-se também Brown (2019). Enfim, outra autora que reforça este ponto em obra recente é Cordelli $(2020$, p. 9) ao tratar sobre o que define como Estado privatizado, "uma caracterização descritiva de um sistema de governo em que a distinção entre cargos públicos e contratos privados esmorece, e onde a administração pública é amplamente transferida para atores privados". Nesse registro, um Estado que privatiza parte considerável de suas funções compromete de maneira indelével sua legitimidade ao deixar cidadãos e cidadãs à mercê da vontade unilateral de atores privados, o que compromete "o próprio fundamento lógico que justifica e compele à existência das instituições políticas e democráticas em primeiro lugar" (CORDELLI, 2020, p. $10)$.
} 
investigar os níveis de participação e volatilidade eleitoral. Destacando que as pesquisas mais recentes se utilizavam de dados agregados para medir tendências quanto a esses indicadores, e que por isso levavam a análises matizadas (e otimistas) sobre a recente queda do comparecimento e variabilidade eleitoral, adotou uma perspectiva similar àquela de pesquisadores que estudam variações climáticas. Afinal, ainda que nem sempre seja possível observar grandes aumentos ou quedas de temperatura em cada ocasião, ou mesmo uma tendência linear em um período, a frequência com que ocorrem altos ou baixos em determinado espaço de tempo pode indicar padrões perceptíveis. Assim, Mair observa que os registros de recordes de baixa participação eleitoral nos países europeus ocorreram majoritariamente em eleições dos anos 1990 (40\%) e 2000 $(37.8 \%)$ em um conjunto de seis décadas ${ }^{18}$. Ainda que possam ocorrer variações pontuais, a direção dos resultados indica uma progressiva diminuição do comparecimento eleitoral. Igualmente, os recordes de alta volatilidade se concentram nessas mesmas décadas $\left(33.3 \%\right.$ e $26.7 \%$ respectivamente) ${ }^{19}$. Com base nesses parâmetros, observa-se que a estabilidade das escolhas do eleitorado - e a previsibilidade dos resultados - tem caído, o que pode indicar um comportamento cada vez mais contingente do eleitorado.

A diminuição do envolvimento popular na política convencional revela-se também quanto a dois outros indicadores. A identificação partidária, medida por meio de dados de survey aplicados entre as décadas de 1960 e 1990, revela uma queda expressiva no número de pessoas que se sentem identificadas com algum partido em onze de treze países considerados no estudo - em que os dados estavam disponíveis (MAIR, 2013, p. 35). É importante notar que diminuiu significantemente o número de pessoas fortemente identificadas com os partidos e que essa tendência se revela aplicável à maior parte dos países em análise. O mesmo ocorre com o número de pessoas filiadas: se nos anos 1980 existiam dúvidas sobre a queda no número de associados, a partir dos

\footnotetext{
${ }^{18}$ O comparecimento eleitoral na Europa, em média, caiu pela primeira vez abaixo de $80 \%$ na década de 1990 (77.6\%) e em seguida para 75.8\% nos anos 2000. Onze dos quinze países registraram suas piores médias na década de 1990 (MAIR, 2013, p. 23-25).

${ }^{19}$ A década de 1990 foi a primeira das cinco a figurar com índices médios de volatilidade acima de $10 \%$, além de constar com a maior diferença com relação à década anterior. É necessário observar que "dados de volatilidade mostram-se inevitavelmente mais erráticos que os dados de comparecimento, sendo muito responsivos a crises políticas bem como mudanças institucionais e socio-estruturais", contudo, as tendências mostram-se notáveis (MAIR, 2013, p. 32-34).
} 
anos 1990 apresentou-se uma forte tendência de queda - medida com dados oficiais dos partidos (MAIR, 2013, p. 38). É possível contestar que tais evidências não apresentam grandes novidades; é verdade, por exemplo, que Hay (2007) já havia apresentado impressões similares, destacando ainda a diminuta participação convencional de pessoas mais jovens. Não obstante, o que chama atenção na análise de Mair (2013, p. 21) é a convergência desses diferentes indicadores, que apontam na mesma direção, e a consistência dos achados entre 'virtualmente' todos os países quando considerados individualmente e não agregados -, dois fatores que não eram comuns em pesquisas comparadas ${ }^{20}$.

Tratei acima sobre o que Hay (2007) classificou como o problema da demanda, mas o problema da oferta é igualmente relevante para Mair (2013), como enfatizei no início da subseção. Em especial, o autor identificou um movimento de neutralização do conflito e das diferenças entre os partidos políticos que se desenvolveu nos últimos trinta anos. "Ocorreu uma redução na intensidade da polarização ideológica" (MAIR, 2013, p. 45, tradução livre) em que, por um lado, partidos anti-sistema buscaram moderar suas demandas ou simplesmente deixaram de atuar - ainda que existam partidos extremistas eles já não advogam por um completo rompimento do regime; por outro, aqueles partidos competitivos eleitoralmente passaram progressivamente a caminhar para o centro, colocando em prática uma política de consenso, em que qualquer partido pode vir a governar com maioria ou pela formação de coalizões. 0 efeito dessa última mudança foi uma 'despartidarização' da formulação de políticas públicas (MAIR, 2013, p. 52): os partidos passaram a governar de maneira muito similar

\footnotetext{
20 Seguindo a mesma metodologia de Mair mas com uma amostra maior, de 22 países considerados desenvolvidos, Schafer e Streeck (2013, p. 10-17) encontram tendências similares. Por exemplo, a média de participação em eleições parlamentares (um índice otimista perto de eleições regionais) saiu do maior valor de 84.1\% na década de 1960 para 72.5\% nos anos 2000-2011 (SCHAFER; STREECK, 2013, p. 11). Consultando os dados da mesma base utilizada pelos autores (IDEA), no dia 10 de julho de 2021 e para o mesmo conjunto de países, é possível extrair uma média de 71.05\% na década de 2010-2019 (apenas Austrália, Bélgica, Grécia e Luxemburgo possuem voto compulsório, em diferentes níveis de sanção). Como se afirma no trecho a que se refere esta nota, o que é marcante é a convergência dos indicadores entre diferentes países, e tanto é assim que nenhum dos autores citados trata a fundo sobre diferenças entre sistemas eleitorais e índices socioeconômicos, por exemplo. Ainda que se reconheça a pertinência desses aspectos contextuais dos países, eles estão além do alcance deste trabalho.
} 
- ou oferecer plataformas eleitorais e programas similares - e a se diferenciar cada vez menos. Campanhas eleitorais que buscam maximizar votos apelando a todo o eleitorado (catch-all) tendem, também, a fragilizar sua base societária. É necessário destacar que essa indiferenciação entre partidos políticos mainstream a cargo dos governos, e a desconfiança da população daí proveniente, teve o efeito de inflar a popularidade de partidos extremistas de direita ou anti-establishment nos últimos anos, tornando-os competitivos eleitoralmente - acontecimento que se encontrava em seus primórdios quando Mair escrevia sua obra, antes de falecer. Encontra-se em curso, assim, uma exacerbação das tendências que ele caracterizou naquele momento, com maiores riscos à democracia tanto vindos do sistema político quanto provenientes de conflitos no nível societário. Retornarei a este ponto na sequência.

A percepção popular de esvaziamento de sentido na atuação dos partidos identificado pelo autor vai mais longe, para retomar a discussão sobre a crescente contradição entre suas funções representativa e governativa ${ }^{21}$. Afinal, a alienação das pessoas comuns da política é concomitante à evasão das elites, a despeito das tentativas de reforma e inserção de mecanismos participativos e de transparência (MAIR, 2013, p. 76). Essa fuga pode ser identificada no gradual processo de 're-localização' dos partidos (MAIR, 2013, p. 82): se entendemos que eles ocupam um espaço entre o Estado e a sociedade civil, cada vez mais estão se aproximado do primeiro polo. Um primeiro ponto, já mencionado, é que as organizações partidárias se orientam principalmente às funções de governo e, consequentemente, podem hoje ser classificadas mais como atores estatais do que atores sociais - como ocorria no clássico modelo de partido de massa. A busca por compor o governo ou ocupar cargos torna-se um fim em si mesmo. Observa-se ainda que essas instituições já não possuem os mesmos vínculos (substantivos) com grupos intermediários da sociedade civil, e as redes de contato antes existentes passam a ter um papel cada vez mais reduzido. Se os partidos necessitam

\footnotetext{
${ }^{21}$ Referindo-se a primeira metade do século XX, Mair (2013, p. 81, grifos no original) expõe que "dentro de sua agência ou instituição, o partido garantia dois elementos constitutivos básicos da democracia: representação, por um lado, e, portanto, governo pelo povo; e legitimidade procedural, por outro lado, ou governo para o povo. Em outras palavras, o partido - ou pelo menos o clássico partido de massa dava voz ao povo, enquanto também garantia que as instituições de governo eram responsabilizáveis." Veremos na sequência que a função representativa tem se perdido progressivamente.
} 
crescentemente dos recursos e meios disponibilizados pelo Estado para conduzirem suas atividades, eles também se tornam cada vez menos dependentes de organizações civis - transformando-se em "agências de serviço público" (MAIR, 2013, p. 88, tradução livre), gradualmente menos autônomas, dada a necessidade do Estado regular suas atividades.

Em suma, a função representativa dos partidos políticos está se exaurindo na medida em que eles se dedicam majoritariamente às funções procedimentais e se acomodam em torno do Estado. Se antes as organizações partidárias cumpriam finalidades como de "integrar e mobilizar a cidadania" e de "articulador e agregador de interesses sociais e políticos" (MAIR, 2013, p. 90; 91, tradução livre), hoje o primeiro desses conjuntos é dispensável nas democracias mais longevas e a atividade de articulação e expressão de interesses pode, e vem sendo cumprida, por outras organizações da sociedade civil - de formas cada vez mais estreitas e especializadas. No que tange à agregação, ainda significante em vista da importância de reconciliar demandas divergentes em conjuntos diferenciados de propostas, esta é cada vez mais deslocada das eleições para o governo em si, dos programas partidários para a formulação de políticas públicas e regulações. Tal fato abre oportunidade também para a delegação de decisões para esferas da administração pública ou organizações internacionais insuladas do público em geral, num processo de despolitização (BURNHAM, 2001; HAY, 2007). Quanto às finalidades procedimentais geralmente associadas aos partidos, ganham importância a alocação de membros em cargos públicos (patronagem) e a organização do governo e das atividades parlamentares. Dada a queda no número de filiações, o recrutamento também foi comprometido e é cada vez mais frequente a busca de futuras lideranças entre pessoas notáveis em outros ramos de atividade - celebridades, por exemplo. Enfim, todas essas evidências confluem para o diagnóstico de que "os partidos... tornaram-se parte do Estado" em detrimento da sua presença na sociedade e do seu papel representativo (MAIR, 2013, p. 97, tradução livre).

Encaminhando para o encerramento dessa seção, apresento alguns argumentos que convergem com a análise realizada por Mair. Em dois artigos Roberto Stefan Foa e 
Yascha Mounk trataram sobre a hipótese de que pode estar em curso um processo de desconsolidação democrática $(2016 ; 2017)$. Com base em dados de pesquisas de opinião do World Values Surveys, realizadas entre 1995 e 2014 e que contemplam Estados Unidos e Europa, os autores identificam não uma insatisfação restrita aos governos nacionais mas uma queda na valorização da democracia como sistema de governo, especialmente entre os mais jovens. Em suas palavras, as pessoas "têm se tornado mais cínicas sobre o valor da democracia como um sistema político, menos esperançosas de que qualquer coisa que façam influencie as políticas públicas e mais dispostas a expressar apoio a alternativas autoritárias" (FOA; MOUNK, 2016, p. 7, tradução livre). Para além dos dados que confirmam o menor envolvimento das pessoas em atividades políticas convencionais - que não é compensado significativamente pela participação não convencional - chama a atenção o crescimento do apoio a alternativas autoritárias. Nos Estados Unidos, por exemplo, o percentual de pessoas que achariam 'bom' ou 'muito bom' um governo militar subiu de 6\% em 1995 para 16\% na atualidade, um crescimento que condiz com o aumento do número de pessoas favoráveis a "um líder forte que não precise se preocupar com o congresso e eleições" e por um governo de especialistas (FOA; MOUNK, 2016, p. 12, tradução livre). Por fim, a aceitação de alternativas anti-democráticas é mais expressiva entre pessoas nascidas após 1980 (millennials $)^{22}$, tendência essa que encontra correspondência nos dados referentes à Europa.

Um contraponto às teses apresentadas no primeiro artigo foi publicado no mesmo número do Journal of Democracy por Ronald Inglehart (2016). Em sua intervenção ele argumenta principalmente que os padrões expostos se referem a um fenômeno pontual dos Estados Unidos - dadas as diferenças entre os grupos de idade, comparado com o caso europeu ${ }^{23}$, e o caráter "aterradoramente disfuncional" da democracia norte-

\footnotetext{
22 Os autores destacam ainda que jovens e ricos são especialmente favoráveis a alternativas nãodemocráticas, e não apenas pessoas menos favorecidas, como se considera usualmente (FOA; MOUNK, 2016, p. 13).

${ }^{23}$ Foa e Mounk (2017, p. 6) contra-argumentam: “Contrariamente à resposta de Ronald Inglehart ao nosso ensaio anterior nessas páginas, um padrão similar de coorte é encontrado em todas as democracias de longa data, incluindo Grã-bretanha, Holanda, Suécia, Austrália e Nova Zelandia (ver Figura 1). Em virtualmente todos os casos, a lacuna geracional é gritante, com a proporção de jovens cidadãos que acreditam que é essencial viver em uma democracia caindo para uma minoria".
} 
americana (INGLEHART, 2016, p. 24). Inglehart enumera os fatores que tornam os EUA um caso especial: a paralisia decisória proveniente do confronto entre Executivo e Legislativo no âmbito federal; o grande crescimento da desigualdade de renda; e, por fim, "uma crescente e desproporcional influência política de bilionários" (INGLEHART, 2016, p. 24). Para ele, o aumento nos percentuais de pessoas que apoiam medidas antidemocráticas é modesto, e pode ser confrontado, por exemplo, com dados da mesma fonte que indicam uma maior tolerância a minorias e aceitação da igualdade de gênero. Apesar de tudo, concorda com os autores que a democracia como valor está em decadência na opinião das pessoas em geral, que o apoio a alternativas autoritárias preocupa e conclui advogando por um sistema econômico mais equânime, o que, por consequência, poderia tornar o sistema democrático mais justo e legítimo.

Tomando em conjunto a exposição dos três autores brevemente sintetizada acima, é possível ponderar que a representação política na atualidade tem sido pouco efetiva para equalizar as condições da cidadania de modo que esta possa se envolver a contento nos assuntos políticos da comunidade. Por consequência, isso tem causado efeitos sobre a confiança que as pessoas possuem no sistema democrático, colocando em risco a sua manutenção - a própria existência dos princípios postulados por Manin (1997). Tomando apenas o aumento nos níveis de desigualdade (cf. PIKETTY, 2014) e a influência política de bilionários, como indica Inglehart (2016) - e que della Porta (2015) sintetizou, a respeito das políticas neoliberais de privatização, liberalização e desregulamentação - é possível perceber as diminutas efetividade e responsividade dos governos representativos na atualidade. Em acordo com a análise de Mair, Foa e Mounk (2017) destacam que a desconfiança e o apoio por medidas anti-democráticas reverberam na própria classe política, como demonstra o fenômeno da ascensão de partidos extremistas de direita na Europa (Polônia, Hungria, entre outros) e a eleição de Donald Trump nos EUA - na maioria dos casos com discursos anti-establishment, nacionalistas, xenófobos e autoritários. Os autores se perguntam: "O que acontece com a estabilidade de democracias liberais pujantes quando vários de seus cidadãos não acreditam mais que seu sistema de governo é particularmente legítimo ou mesmo quando vão tão longe como a expressar apoio aberto a formas de regime autoritário?" (FOA; MOUNK, 2017, p. 
9, tradução livre). Os recentes governos implementados nos países mencionados acima neste parágrafo, e mesmo o Brasil sob Bolsonaro neste particular, dão mostras, como no enfraquecimento do Estado de direito, episódios de violência política e ataques aos veículos tradicionais de mídia, entre outras preocupantes evidências.

\section{Representação política em contextos de neoliberalismo e austeridade}

Estamos agora em melhor posição para avaliar alguns trabalhos que tratam sobre o jaez das democracias contemporâneas. Antes disso, destaco brevemente a importância dos conceitos de Estado tributário [Tax State] (SCHUMPETER, 1991 [1918]), Estado endividado [Debt State] e Estado austero [Austerity state] (SCHAFER; STREECK, 2013; cf. STREECK, 2017 [2014]), provenientes da sociologia fiscal, para compreender a profundidade do problema da representação política, mais evidente nos últimos anos após a crise econômica mundial de 2008. Se para Schumpeter (1991, p. 100, tradução livre), citando Rudolf Goldscheid, "o orçamento é o esqueleto do Estado despido de todas as ideologias enganosas" e a maneira como um Estado arrecada tributos e se utiliza dos recursos - as decisões sobre como e onde despendê-los - é um elemento fundamental da política em suas diferentes dimensões, deduz-se então que uma análise sobre a democracia que prescinda desse tema releva-se incompleta. Seguindo a perspectiva do autor austríaco, que escrevia 24 anos antes do clássico Capitalismo, socialismo e democracia, o Estado moderno se constitui como um Estado tributário e as atividades relacionadas à questão orçamentária perpassam todas as esferas da atividade humana em seus territórios, segundo uma compreensão histórica (SCHUMPETER, 1991). No século XX, contudo, é possível perceber que as decisões políticas sobre a estrutura tributária dos Estados não apenas têm favorecido uma parcela minoritária da população e influentes atores econômicos (O'CONNOR, 1977) como comprometeu progressivamente a sua capacidade fiscal. Num contexto de economia capitalista e crescente concorrência entre os Estados pela alocação de capitais e investimentos, ocorreu então um crescimento das dívidas nacionais, especialmente preocupante em cenários de crise econômica (SCHAFER; STREECK, 2013; STREECK, 2017). Tal condição, agravada pela maturação dos Estados de bem-estar e as demandas por gastos sociais, 
levou então à adoção de medidas de aperto orçamentário e a uma conformação classificada na literatura como de austeridade permanente (PIERSON, 2001).

O que se extrai dessa brevíssima síntese é que, em um Estado democrático, as decisões relacionadas ao orçamento e à tributação pertencem ao conjunto de representantes eleitos e eleitas pela população de um determinado local. De acordo com o exposto, essas decisões são fundamentais para determinar as prioridades de um Estado e como as instituições atendem as demandas populares. Se, conforme postula Downs (1960), as eleições representam uma disputa entre orçamentos governamentais prospectivos, e conforme vimos na análise de Mair (2013) as eleições já não são mais o espaço para discussão de propostas substantivas, e os partidos pouco se diferenciam na implementação de políticas, alienando parte das decisões a corpos tecnocráticos, observa-se enfim que a representação se faz pouco ou nada efetiva. Se um governo democrático é aquele em que, entre outras coisas, a população tem a oportunidade de influir na decisão concernente à aplicação dos recursos públicos, conforme se deriva da discussão sobre o conceito de democracia fiscal (GENSCHEL; SCHWARZ, 2013), e grande parte desses recursos não podem ser gastos de maneira discricionária (por já se encontrarem comprometidos por decisões e compromissos pretéritos), igualmente a representação resta gravemente prejudicada ${ }^{24}$. Afinal, em um cenário como este sobressai o poder das elites políticas e econômicas de determinarem a agenda política, isto é, frequentemente segundo um certo entendimento de que não há alternativa possível à política econômica mainstream - cortes de gastos, ajuste fiscal rigoroso, privatizações e desregulamentação da economia. Portanto, do que foi exposto, e mesmo a partir de autores considerados minimalistas, o diagnóstico da crise de

\footnotetext{
${ }^{24}$ De maneira convergente, Tavares e Silva (2020, p. 8, grifo meu) afirmam que "o relativo consenso procedimentalista da teoria democrática erigida ao longo do século XX não se separa, nem mesmo analiticamente, ao menos nas correntes de maior influência e menor ânimo crítico ou normativo, de uma premissa teórica segundo a qual o elemento substantivo inscrito na arrecadação tributária e no orçamento estatal estabelece os termos e os limites da disputa democrática". Desse modo entende-se que "os processos decisórios - desde eleições até a participação institucional - assentam-se sobre uma base substantiva fiscal" (TAVARES; SILVA, 2020, p. 9).
} 
representação se coloca e se reforça a partir da incorporação da dimensão fiscal do Estado - e das desigualdades fomentadas a partir de sua configuração.

Nesse sentido talvez não seja apenas a representação política que esteja perdendo substância, mas a própria democracia. Já no início desse século Colin Crouch (2004) propôs o conceito de pós-democracia, um cenário em que todo o cerimonial da democracia continua a ocorrer normalmente, como as eleições e tudo que elas ensejam, mas a política torna-se uma exibição teatral. Enquanto cidadãos e cidadãs cumprem um papel passivo e quiescente na maior parte do tempo, as decisões de fato estão sendo tomadas em outras instâncias privadas do conhecimento e do controle popular, o que fortalece os interesses das grandes corporações econômicas em detrimento de uma agenda política mais igualitária e redistributiva. Cresce também o cinismo entre as pessoas, uma espécie de "ativismo negativo" (CROUCH, 2004, p. 13) que se guia pela ofensividade e pela vingança, mas não é capaz de engajar e construir alternativas políticas, ampliando a lacuna entre cidadãos e cidadãs e a elite política. Na medida em que o capital é útil à classe política não apenas como fonte de recursos de campanha, mas como fonte de tributos e empregos, movimentando a economia, as elites tornamse dependentes dele. E ao privilegiar os interesses dos lobbies, tornando o Estado 'minimo' para a população e 'máximo' para eles - uma alocação desigual dos recursos existentes -, desprestigiam o processo democrático e a perspectiva das pessoas de ter suas demandas consideradas. Enquanto o Estado de bem-estar é reduzido ao mínimo, o Estado policial recrudesce, e as desigualdades se ampliam, no campo da política convencional, como demonstra Crouch, tudo se passa como uma espécie de comercial televisivo, com efeitos também sobre os partidos políticos.

Esse quadro é reforçado por autores e autoras que tratam sobre o aspecto da despolitização [depoliticisation] na política contemporânea. Compreendendo uma variedade de perspectivas, a noção pode ser entendida como uma mudança no caráter do exercício do poder em que a dimensão política da deliberação e tomada de decisões é depreciada - frequentemente em favor de um entendimento tecnocrático, supostamente objetivo ou neutro (DE NARDIS, 2015). Se a politização de um tema significa deslocá-lo do domínio da necessidade e do destino para o domínio da deliberação e da contingência, tornando-o passível de discussão, decisão e agência 
humana, a despolitização se refere ao movimento contrário: a retirada desse mesmo tema da alçada governamental ou da deliberação pública para o âmbito privado ou para o campo da necessidade (HAY, 2007, p. 61-89). Ainda que no funcionamento usual das democracias ambos os movimentos ocorram constantemente, quando determinadas pautas deixam de ser ou voltam a ser sujeitas à intervenção política, o que se pode perceber na atualidade é que matérias contenciosas e que incidem de maneira importante na vida das pessoas tendem fortemente para a despolitização especialmente aquelas que poderiam enfrentar a contento as crescentes desigualdades social e econômica. Para Hay (2007) isso se explica por uma generalizada visão negativa da política potencializada pelas elites governamentais e econômicas que seguem os pressupostos da teoria da escolha pública - que se compatibilizam com a implementação de uma política econômica neoliberal. Em suma:

\footnotetext{
"Despolitização, na literatura acadêmica, serve para insular os politicos e suas escolhas, imunizá-los da responsabilidade, prestação de contas e crítica. É uma recusa das obrigações democráticas de um governo aos seus cidadãos em um regime democrático. É um mecanismo conveniente para desarmar a oposição, varrendo para debaixo do tapete temas potencialmente conflituosos. E é uma técnica que pode se mostrar tanto especialmente útil e particularmente insidiosa onde a trajetória da reforma escolhida é certa de manifestar impopularidade" (HAY, 2007, p. 92, tradução livre).
}

A despolitização, em seus efeitos concretos, foi caracterizada de diferentes formas na literatura. Wood e Flinders (2014) fazem um esforço conceitual para categorizar as diferentes perspectivas nas quais essa noção foi utilizada. A primeira é a despolitização governamental, que enfatiza os aspectos institucionais que promovem, por exemplo, autonomia com relação ao elemento político da tomada de decisões - conforme destaca Burnham (2001) quando trata do deslocamento de tarefas do partido governista para corpos 'não-políticos', por exemplo, quando se atribui independência ao Banco Central. A imposição de regras que constrangem a discricionaridade dos representantes e a diluição da tomada de decisão em longas cadeias - que compromete a atribuição de responsabilidade - também são aspectos enfatizados nessa perspectiva. A segunda é a despolitização societária que compreende estudos sobre o estreitamento do debate 
público quanto às escolhas disponíveis para determinados problemas. Aqui não apenas os governos influenciam negativamente, mas também aqueles grupos de interesse, associações, movimentos sociais, entre outros, que particularizam ou restringem o debate ao seu ponto de vista ou demandas. Assim, "um regime despolitizado é também uma 'democracia sem escolhas', em que a única questão centra-se em quem selecionar para administrar um projeto político predestinado" (WOOD; FLINDERS, 2014, p. 160, tradução livre). Finalmente, a terceira perspectiva, da despolitização discursiva, possui como foco a linguagem e as ideias. Ela se manifesta, por exemplo, em situações quando um determinado tema centra-se em pontos de vista técnicos, administrativos, em que os objetivos e as escolhas são reduzidas. "A promoção de um tema, mas ao mesmo tempo de uma única interpretação e a rejeição da escolha poderia, então, criar uma forma de despolitização a partir da perspectiva discursiva" (WOOD; FLINDERS, 2014, p. 161, tradução livre). Não é dificil estabelecer um paralelo com diversas manifestações de discursos de matiz neoliberal na atualidade.

A conformação de um cenário em que essas diferentes formas de despolitização interagem e se reforçam mutuamente tem, da mesma forma, o potencial de ampliar as desigualdades sociais e provocar o que della Porta (2015) classifica como uma crise de responsabilidade. O mérito da autora nessa obra de maneira geral é trazer a discussão sobre o capitalismo, e a persistência do elemento de classe, para analisar o comportamento e atuação dos movimentos sociais na contemporaneidade. Afinal, as recentes ondas de protestos ocorridas no mundo desde a crise de 2008 só podem ser entendidas num contexto, como enfatizado por Crouch (2004), em que o Estado intervém sobremaneira em favor dos grandes interesses econômicos em detrimento dos direitos sociais da população - por meio de políticas de "desregulamentação, privatização e liberalização" (DELLA PORTA, 2015, p. 113). Na medida em que as decisões governamentais são constrangidas pelo elo de responsabilidade com os 'mercados' e com diferentes agências e organizações internacionais, a democracia de fato pode ser reduzida ao mínimo, tornando o governo impermeável às demandas da população e negando-Ihes sua soberania. Assim, podemos perceber a sua convergência com os autores e autoras tratados ao longo desse trabalho: a crise de responsabilidade se dá não porque o Estado está intervindo muito - em contraposição à crise de 
legitimidade postulada por Habermas nos anos 1970 - mas porque ele está intervindo pouco (em favor da cidadania), "dado o declínio da competência pública e a perda de soberania, acompanhada por uma retórica de despolitização. Isso foi alcançado não por meio do funcionamento de uma grande e oculta mão invisível do mercado, mas sim por meio de decisões políticas" (DELLA PORTA, 2015, p. 152, tradução livre). A crise econômica conflui com a crise política, comprometendo a representação e a confiança de cidadãos e cidadãs no sistema democrático.

Finalizo essa avaliação da democracia representativa em contextos de neoliberalismo e austeridade, pertinentemente, com os efeitos mais fundamentais que podem acarretar de tal conformação. Como apresenta Wendy Brown (2015) a exposição da democracia à racionalidade neoliberal tem o efeito não apenas de reduzir a nada o seu ideal ou projeto, mas de converter a liberdade em sacrifício na subjetividade das pessoas. Compreendendo que a democracia liberal não é a forma última de um ideal igualitário ${ }^{25}$, mas que mesmo assim carrega um potencial crítico e de contestação da política tal como se conforma, a autora expõe que mesmo essa democracia mínima, despida de substância e excludente, está em risco na contemporaneidade frente à uma racionalidade governativa neoliberal. Nesse registro, "os últimos traços republicanos clássicos da cidadania formulados como engajamento com o interesse público" são transfigurados em "sacrifício cidadão" (BROWN, 2015, p. 210, tradução livre). Assim, as pessoas são conduzidas a abrir mão de direitos sociais e trabalhistas fundamentais para a sua reprodução por meio de um 'sacrifício conjunto' em contextos de austeridade, sacrifício este que é feito em nome de um poder supremo - aquele dos 'mercados' "do qual estamos radicalmente dependentes, mas que não nos deve nada" (BROWN, 2015, p. 216, tradução livre). Tal estado de coisas não ocorre sem contradições, de forma que podem ocorrer ações de resistência popular pelo questionamento do sacrifício cidadão - como pode ser observado nos protestos ocorridos na Espanha e nos Estados Unidos em 2011, entre outros posteriormente, como na França em 2016 (Nuit debout)

\footnotetext{
25 Já que está permeada de fundamentos problemáticos e que normatizam princípios do homem branco, burguês, heterossexual, de família tradicional (BROWN, 2015, p. 205).
} 
e 2018 (Mouvement des gilets jaunes). Tal análise, portanto, converge em vários pontos com a literatura sobre a despolitização conforme exposto acima.

Por limitada que seja a amostra da literatura sobre a representação 'realmente existente' exposta nesta seção, temos elementos suficientes para uma crítica das abordagens canônicas. Do exercício proposto neste artigo emerge o problema do contexto em que se dá a relação de representação, que afeta também a sua efetividade. Em Estados não apenas democráticos, mas capitalistas, em que a desigualdade torna-se um problema relevante (Piketty, 2014), explicita-se o distanciamento entre representantes e representados ${ }^{26}$. Os imperativos da responsividade e do atendimento ao interesse público levantados por Pitkin (1967) tornam-se mais complicados. O processo democrático se desenrola em uma esfera pública composta por diferentes pontos de vista que de forma alguma se colocam em posição de igualdade - a questão sobre qual é o melhor interesse da sociedade não é transparente e está em disputa de forma desigual. Nesse cenário o poder do voto nas mãos da cidadania, enfatizado por Manin (1997), perde a sua efetividade na medida em que o eleitorado está sujeito a tomar decisões sobre temas complexos com base não apenas em informações enganosas, mas também parciais - e sob influência de uma mídia longe da neutralidade, administrada ou financiada por poderosos interesses. Sob esse ponto de vista é difícil conceber como funcionaria a representação como processo político, oportunamente proposta por Urbinati (2006b), quando as assimetrias sociais se elevam a um nível tão intenso não apenas entre representantes e representados, mas também entre a própria cidadania - afetando a qualidade da deliberação pública. Por tudo isso, ao tratar sobre a representação é necessário ter em conta o fato de que ela se realiza sob certas condições sociais e econômicas legadas historicamente - e a sociologia fiscal nos auxilia a dar conta dessas circunstâncias. Essa conduta teria também o potencial de contribuir com o resgate do sentido da política como meio de realizar o bem público por meio de

\footnotetext{
${ }^{26}$ Tratando sobre a cooptação das instituições eleitorais Mounk (2019), por exemplo, dá conta de como o ambiente em que transitam os representantes conforma seu distanciamento dos cidadãos e das cidadãs comuns. Da necessidade de afagar financiadores e obter apoio de veículos de mídia, passando pela profissionalização das campanhas e ausência de vínculo com os distritos em que concorrem, e enfim à formação em cursos e universidades de elite em seus países. Tudo isso contribui para que, com o tempo, seus juízos, opiniões e interesses coincidam com aqueles das elites econômicas.
} 
diferentes medidas, desqualificando aqueles e aquelas que percebem e enaltecem a despolitização como um fenômeno benéfico.

\section{Considerações finais}

Examinando o conceito de representação, a forma como ele foi tratado empiricamente e os limites das abordagens recentes relacionadas ao tema, este estudo buscou tanto quanto possível evidenciar as convergências entre as crises de representação e fiscal do Estado. No que se refere aos trabalhos teóricos sobre a representação, percebe-se a diminuta ênfase sobre as desigualdades sociais e a economia política dos Estados: se o governo representativo se dá em um Estado democrático, mas também capitalista, o caráter da relação de representação contempla outras variáveis. Ainda que seja desejável, de um ponto de vista normativo, que sejam propostas teorias da representação que enfatizem elementos ideais do que se espera de um governo representativo, não é possível referir-se à conformação das democracias contemporâneas sem uma ampliação de seus pressupostos. Schafer e Streeck (2013), por exemplo, referem-se à possibilidade de que os governos democráticos não sejam responsáveis apenas frente ao povo, ao eleitorado comum, mas aos mercados e seus agentes. Nesse mesmo sentido, como vimos, argumentou Mair (2009) a respeito da incompatibilidade, em seus termos, entre responsabilidade e responsividade governamental. Indo mais longe, della Porta (2013) identificou uma crise de responsabilidade, em que os governantes têm perdido a capacidade de atender as demandas da população frente às exigências do mercado internacional e instituições supranacionais. Em suma, para melhor compreender a relação entre representantes e representados, é necessária uma perspectiva mais ampla sobre a relação entre economia e política.

Com relação aos trabalhos empíricos, os achados de Mair (2013) referentes ao comportamento dos cidadãos e cidadãs e da elite política - em especial dos partidos como instituições representativas - convergem em certa medida com os diagnósticos feitos por autores e autoras como Crouch (2004), della Porta (2013), Brown (2015), além 
daqueles que trataram sobre o aspecto da despolitização (HAY, 2007; WOOD; FLINDERS, 2014). Pode-se interpretar que o concomitante afastamento entre cidadãos e cidadãs e as elites políticas se deve à forma como os governos representativos funcionam atualmente, vinculados a um tipo específico de Estado, envolto numa crise financeira e dependente de agências, instituições e influentes atores econômicos - o que afeta o caráter da representação nessas democracias. Além disso não se pode descartar o sentido negativo, e mesmo pejorativo, que a política como prática social adquiriu com o passar das décadas (HAY, 2007), entendimento este difundido tanto entre as pessoas comuns quanto entre as elites políticas - o que deu margem tanto para o aprofundamento de políticas neoliberais como a consequente ascensão da extrema direita em diversos países.

Tal é o quadro que pode ser feito, ao menos no que se refere ao Norte global. Resta ainda uma ampla agenda de pesquisa no que concerne aos países do Sul, e especificamente o Brasil. Ainda que alguns paralelos possam ser feitos, principalmente no processo ainda em curso de crise da democracia acoplada a uma crise econômica que vem desde 2014 e que levou à aprovação de uma draconiana medida de ajuste fiscal em 2016 (Novo Regime Fiscal) ${ }^{27}$ e à eleição de um presidente de extrema-direita em 2018, muito do que foi exposto por Mair com relação aos partidos políticos e seus vínculos com a sociedade merece uma avaliação mais aprofundada - e mesmo sobre a hipótese do crescimento da abstenção eleitoral, conforme um debate em curso há alguns anos ${ }^{28}$. Assim a expectativa é que este trabalho ofereça uma contribuição para o aprofundamento dos estudos sobre representação, agora sob uma perspectiva da economia política dos Estados, e o desenvolvimento de pesquisas sobre a efetividade da representação política nesses países.

\footnotetext{
${ }^{27}$ Os trabalhos de Tavares e Silva (2020) e Lelis (2020) oferecem relevante contribuição ao explorarem em detalhes os acontecimentos que levaram à aprovação da Emenda Constitucional 95/2016 que instituiu o Novo Regime Fiscal e seus efeitos mais duradouros sobre a democracia brasileira.

${ }^{28}$ Cf. Fernando Limongi. Analistas superestimam absenteísmo eleitoral em 2016. Folha de S. Paulo, llustríssima, 13 nov. $2016 . \quad$ Disponível em: <http://www1.folha.uol.com.br/ilustrissima/2016/11/1831315-analistas-superestimam-absenteismoeleitoral-em-2016.shtml>. Acesso em: 2 abr. 2021.
} 


\section{Referências bibliográficas}

AMARAL, Oswaldo E. do. O que sabemos sobre a organização dos partidos políticos: uma avaliação de 100 anos de literatura. Revista Debates, v. 7, n. 2, p. 11-32, mai./ago. 2013. DOI: $\underline{10.22456 / 1982-5269.38429}$

BENEDITO, Sérgio Mendonça. Sobre a expansividade da democracia: uma proposta de reinterpretação do minimalismo democrático. Revista Sem Aspas, Araraquara, v. 8, n. 1, p. 88-103, jan./jun. 2019. DOI: 10.29373/sas.v8i1.12597

BROWN, Wendy. Epilogue: Losing bare democracy and the inversion of freedom into sacrifice. In: . Undoing the Demos: Neoliberalism's Stealth Revolution. New York: Zone Books, 2015. p. 201-222.

BROWN, Wendy. Politics must be dethroned. In: In the ruins of neoliberalism: the rise of antidemocratic politics in the west. New York: Columbia University Press, 2019. p. 55-87.

BURNHAM, Peter. New Labour and the Politics of depoliticisation. British Journal of Politics and International Relations, vol. 3, n. 2, p. 127-149, june 2001. DOI: 10.1111/1467-856X.00054

CASTIGLIONE, Dario; WARREN, Mark E. Rethinking democratic representation: eight theoretical issues. In: DISCH, Lisa; VAN DE SANDE, Mathijs; URBINATI, Nadia (Org.). The constructivist turn in political representation. Edinburgh: Edinburgh University Press, 2019 [2006]. p. 21-47.

CORDELLI, Chiara. The privatized state. Princeton: Princeton University Press, 2020.

CROUCH, Colin. Post-Democracy. Cambridge: Polity Press, 2004.

DELLA PORTA, Donatella. Social Movements in Times of Austerity. Cambridge: Polity Press, 2015.

DE NARDIS, Fabio. Comment on Loris Caruso/3. Political Opportunity Structures, Social Movements, and the De-Politicization of contemporary Politics. Sociologica, Fascicolo 3, p. 1-17, settembre-dicembre 2015. DOI: $\underline{10.2383 / 82474}$

DOVI, Suzanne. Political Representation. The Stanford Encyclopedia of Philosophy, Spring 2017. Disponível em: <https://plato.stanford.edu/archives/spr2017/entries/political-representation/>. Acesso em: 2 abr. 2021. 
DOWNS, Anthony. Why the Government budget is Too Small in a Democracy. World Politics, v. 2, n. 14, p. 541-563, 1960. DOI: $10.2307 / 2009337$

FOA, Roberto Stefan; MOUNK, Yascha. The Democratic Disconnect. Journal of Democracy, vol. 27, n. 3, jul. 2016. DOI: 10.1353/jod.2016.0049

FOA, Roberto Stefan; MOUNK, Yascha. The Signs of Deconsolidation. Journal of Democracy, vol. 28, n. 1, jan. 2017. DOI: 10.1353 /jod.2017.0000

FOMINAYA, Cristina Flesher. Social Movements and Globalization: How Protests, Occupations, and Uprisings are Changing the World. Basingstoke: Palmgrave Macmillan, 2014.

GENSCHEL, Philipp; SCHWARZ, Peter. Tax Competition and Fiscal Democracy. In: SCHAFER, Armin; STREECK, Wolfgang (Org.). Politics in the Age of Austerity. Cambridge: Polity Press, 2013. p. 59-83.

HAY, Colin. Why we Hate Politics. Cambridge: Polity Press, 2007.

HOLMES, Stephen; SUNSTEIN, Cass R. The Cost of Rights: Why Liberty Depends on Taxes. New York: W. W. Norton, 1999.

HUNTINGTON, Samuel. A terceira onda: a democratização no final do século XX. São Paulo: Ática, 1994.

INGLEHART, Ronald F. Devemos nos preocupar? Journal of Democracy [em português], v. 5, n. 2, p. 23-31, out. 2016.

KATZ, Richard; MAIR, Peter. Changing models of party organization and party democracy: the emergence of the cartel party. Party Politics, vol. 1, n. 1, p. 5-28, 1995. DOI: $10.1177 / 1354068895001001001$

KRIESI, Hanspeter. Mobilization of protest in the age of austerity. In: ANCELOVICI, Marcos; DUFOUR, Pascale; NEZ, Heloise (Org.). Street politics in the age of austerity. Amsterdam: Amsterdam University Press, 2016. p. 67-90.

LANDEMORE, Hélène. A democracia representativa é realmente democrática? Dois pontos:, Curitiba; São Carlos, vol. 13, n. 2, p. 143-156, out. 2016. DOI: $10.5380 /$ dp.v13i2.43063

LELIS, Davi. Direitos sem dinheiro: do Novo Regime Fiscal à Covid-19. Ciências Sociais Unisinos, São Leopoldo, v. 56, n. 2, p. 164-176, maio/ago. 2020. DOI: 10.4013/csu.2020.56.2.05

LINZ, Juan J.; STEPAN, Alfred. A transição e consolidação da democracia. A experiência do Sul da Europa e da América do Sul. São Paulo: Paz e Terra, 1999. 
MAIR, Peter. Representative versus Responsible Government. Max-Planck-Institut für Gesellschaftsforschung, Working Paper 09/8, 2009. Disponível em: <http://www.mpi-fgkoeln.mpg.de/pu/workpap/wp09-8.pdf>. Acesso em: 2 abr. 2021.

MAIR, Peter. Ruling the Void: The Hollowing of Western Democracy. London: Verso, 2013.

MANIN, Bernard. As metamorfoses do governo representativo. Revista Brasileira de Ciências Sociais, São Paulo, v.10, n, 29, out., 1995. Disponível em: <http://anpocs.com/images/stories/RBCS/rbcs29_01.pdf >. Acesso em: 2 abr. 2021.

MANIN, Bernard. The Principles of Representative Government. New York: Cambridge University Press, 1997.

MANIN, Bernard; PRZEWORSKI, Adam; STOKES, Susan C. Eleições e representação. Lua Nova, São Paulo, n. 67, p. 105-138, 2006. DOI: 10.1590/S0102-64452006000200005

MANIN, Bernard. Publikumsdemokratie Revisited. Nachwort Zur Deutschen Ausgabe. In: . Kritik der Reprasentativen Demokratie. Berlin: Matthes \& Seitz, 2007. p. 327-

349. Disponível em: <http://cespra.ehess.fr/docannexe/fichier/556/PostScript.\%20German.pdf>. Acesso em: 2 abr. 2021.

MANSBRIDGE, Jane. Rethinking representation. The American Political Science Review, v. 97, n. 4, p. 515-528, nov. 2003.

MARTIN, Isaac William; MEHROTRA, Ajay K.; PRASAD, Monica. The thunder of history: the origins and development of the new Fiscal Sociology. In: (Org.). The new fiscal sociology: taxation in comparative and historical perspective. Cambridge: Cambridge University Press, 2009. p. 1-27.

MIGUEL, Luis Felipe. Democracia e representação: territórios em disputa. São Paulo: Editora Unesp, 2014.

MOUNK, Yascha. Direitos sem democracia. In: O povo contra a democracia: por que nossa liberdade corre perigo e como salvá-la. São Paulo: Companhia das Letras, 2019. p. 74-124.

O'CONNOR, James. USA: A crise do Estado capitalista. Tradução de João Maia. São Paulo: Paz e Terra, 1977.

ORTIZ, Isabel; BURKE, Sara; BERRADA, Mohamed; CORTÉS, Hernán. World Protests 20062013. Working Paper, Initiative for Policy Dialogue and Friedrich-Ebert-Stiftung. New York, Sep. 2013. 
PHILLIPS, Anne. Democracy and representation: or, why should it matter who our representatives are? In: (Org.). Feminism \& Politics. Oxford: Oxford University

Press, 1998. p. 224-240.

PIERSON, Paul. Coping with Permanent Austerity Welfare State: Restructuring in Affluent Democracies. In: (Org.). The New Politics of the Welfare State. Oxford: Oxford University Press, 2001. p. 80-106.

PIKETTY, Thomas. Capital in the Twenty-First Century. Cambridge, MA: Harvard University Press, 2014.

PITKIN, Hanna Fenichel. The Concept of Representation. Berkeley: University of California Press, 1967.

PLOTKE, David. Representation is Democracy. Constellations, v. 4, n. 1, p. 19-34, 1997. DOI : $\underline{10.1111 / 1467-8675.00033}$

PRZEWORSKI, Adam. A social-democracia como um fenômeno histórico. In: Capitalismo e social democracia. São Paulo: Companhia das Letras, 1989. p. 19-65.

REHFELD, Andrew. Towards a General Theory of Political Representation. The Journal of Politics, v. 68, n. 1, p. 1-21, fev. 2006. DOI: 10.1111/j.1468-2508.2006.00365.x

SAWARD, Michael. The representative claim. Oxford: Oxford University Press, 2010.

SCHAFER, Armin; STREECK, Wolfgang. Introduction. In: (Org.). Politics in the Age of Austerity. Cambridge: Polity Press, 2013. p. 1-25.

STREECK, Wolfgang. Buying time: the delayed crisis of democratic capitalism. 2 ed. London: Verso, 2017 [2014].

SCHUMPETER, Joseph A. The Crisis of the Tax State. In: SWEDBERG, Richard (Org.). Joseph A. Schumpeter: The Economics and Sociology of Capitalism. Princeton, NJ: Princeton University Press, 1991 [1918]. p. 99-140.

TAVARES, Francisco; SILVA, Gustavo. A ciência política diante do Novo Regime Fiscal: para uma agenda de pesquisas sobre democracia e austeridade. Dados, Rio de Janeiro, v. 63, n. 2, p. 1-39, 2020. DOI: $10.1590 / 001152582020207$

TILLY, Charles. Democracy. Cambridge: Cambridge University Press, 2007.

TILLY, Charles. Extraction and democracy. In: MARTIN, Isaac William; MEHROTRA, Ajay K.; PRASAD, Monica (Org.). The new fiscal sociology: taxation in comparative and historical perspective. Cambridge: Cambridge University Press, 2009. p. 173-182.

URBINATI, Nadia. O que torna a representação democrática? Lua Nova, São Paulo, n. 67, p. 191-228, 2006a. DOI: 10.1590/S0102-64452006000200007 
URBINATI, Nadia. Representative Democracy: Principles and Genealogy. Chicago: University of Chicago Press, 2006b.

URBINATI, Nadia. Crise e metamorfoses da democracia. Revista Brasileira de Ciências Sociais [online], vol. 28, n. 82, p. 5-16, jun. 2013. DOI: 10.1590/S0102$\underline{69092013000200001}$

WOOD, Matt; FLINDERS, Matthew. Rethinking Depoliticisation: Beyond the Governmental. Policy \& Politics, vol. 42, n. 2, p, 151-170, 2014. DOI: 10.1332/030557312X655909.

YOUNG, Iris Marion. Inclusion and democracy. Oxford: Oxford University Press, 2002.

Tramitação do artigo na revista Submetido: 03/04/2021

Revisões requeridas: 25/06/2021 Versão revista: 12/07/2021

Revisões requeridas: 19/09/2021 Nova versão revista: 03/10/2021 Aceito: 08/10/2021 